\title{
Escritos en el lenguaje del exilio ${ }^{1}$
}

\author{
Mónica Marinone
}

1 Este ensayo toma algunos aspectos de un capítulo que escribí para el volumen Escrituras y exilios, del cual soy co-autora.

Doctora en Letras por la Universidad de Buenos Aires. Especialista en literatura y cultura latinoamericanas, docente e investigadora en la Facultad de Humanidades- CELEHIS (Universidad Nacional de Mar del Plata) y profesora invitada por universidades argentinas y del exterior. Ha desarrollado sus últimas investigaciones sobre el Caribe continental, que derivaron en los ensayos Escribir novelas. Fundar naciones y Rómulo Gallegos. Imaginario de Nación, siendo convocada para la actualización del Diccionario General de Literatura Venezolana (DGLV). Es co-autora de La reinvención de la memoria, Senderos en el bosque de palabras y Escrituras y exilios en América Latina. Ha publicado artículos en volúmenes colectivos, revistas nacionales e internacionales, coordinado antologías y, en colaboración, tres volúmenes internacionales: Grabar lo que se desvanece. Narrativas de la memoria en América Latina; Viaje y Relato en Latinoamérica, y Noticias del diluvio. Textos latinoamericanos de las últimas décadas. Está escribiendo, por solicitud de una editorial española, un ensayo sobre las novelas de Denzil Romero.

Contacto: mmarinone@gmail.com 
PALAVRAS-CHAVE

Literatura; Exilio;

Lenguaje; Roa Bastos

KEYWORDS

Literature; Exile;

Language; Roa Bastos
RESUMEN

El ensayo explora textos de Augusto Roa Bastos, un escritor modélico respecto de una experiencia de exilio compleja, siempre refigurada en su escritura. Si cualquier exilio geográfico implica un exilio de la lengua (Roa escribió su narrativa completa lejos del Paraguay), su propio sistema cultural se ve marcado, desde el dominio colonial hispánico, por una situación de "diglosia" como exilio (lingüístico/cultural) constitutivo. Por ello apelo al concepto "lenguaje del exilio" y reviso desde un texto poético a una serie de relatos, ciertas imágenes y metáforas que se alzan como signos del trabajo de Roa sobre el castellano, una retórica que propicia el trazo de líneas y núcleos de resonancia y anclaje o escritura superpuesta, entramada a la convencional. 
This essay explores Augusto Roa Bastos's texts, an exemplary writer when we focus on exile as a complex experience that comes up in writing. If geographic exile is an exile from one's own language (Roa Bastos wrote his best narrative while living outside Paraguay), his cultural system is marked by a "diglossic" situation as constitutive exile (both linguistic and cultural). Thus, the concept "language of exile" becomes useful in the explanation of a poetic text and some narratives, images, and metaphors that we consider signs of Roa Bastos's outstanding work in relation to Spanish, a distinctive writing style woven in the fabric of the conventional one. 
Augusto Roa Bastos se constituyó, en el ámbito latinoamericano, como un escritor modélico de ciertas experiencias de exilio refiguradas en su escritura. "Escribo en el lenguaje del exilio" solía decir y la decodificación de una sentencia de esta índole puede permanecer en lo obvio pues su biografía describe un círculo de partidas y de regresos: como se sabe, nació en 1917 en Paraguay, precisamente donde se radicó para morir, en 2005; irse fue, como en todos los exilios, el denominador común, primero de su tierra, después de Argentina, finalmente de Francia. "No hago distingos entre el exilio forzoso y el voluntario" decía también, desactivando la asociación inmediata de su "irse" con la persecución política o el riesgo de muerte, causas conocidas en su historia de vida. Amparada en esta desactivación y convencida de que en su caso cada frase (cada sentencia) abre a una densidad conducente a reflexión, me interesa la referencia tajante a un "lenguaje del exilio" (de ahí mi uso sentencia) como clave de una búsqueda ininterrumpida del mejor lugar -la eu-topía - a través de/en la escritura, ese locus donde todo resultaría posible, aun la permanencia.

La pasión de narrar se hace visible no solo en las ficciones literarias de Roa, también en sus ensayos o en cualquier intervención escrita u oral que pueda recordarse. La opción no fue arbitraria al menos por dos razones: el gesto narrativo es uno de los privilegiados entre las formas de expresión verbales, la estructura comunicacional que permite procesar la experiencia humana a fin de comprenderla, dar cuenta de la misma desde tramas que instauran órdenes, ya para reforzar la tradición de una coherencia, ya para romper con ella. Y es el gesto capital en culturas de base oral como la paraguaya, también por su funcionalidad, concentrar cierta cantidad de saber en una manifestación sustancial y relativamente extensa que se vuelve perdurable. $^{2}$

En relación, para Roa la novela fue el ámbito privilegiado, por lo señala- 
do y por esa marca que la distingue. Me refiero a la entropía o mecanismo que admite mostrar lo más posible a través de un relato, suerte de puesta en escena de la desconfianza, la incertidumbre, la sospecha, instauradoras de una resonancia que se percibe infinita y empieza, es claro, por los propios materiales y procedimientos. ${ }^{3}$ Entonces, porque la novela resulta, como ha señalado Steiner, uno de los instrumentos convenientes de debate y percepción dado su carácter de metáfora-puente entre mundos y saberes, posibilidad aprovechada en su caso de modo obsesivo desde Yo el Supremo [1974] en adelante, para intervenir e incidir políticamente desde la producción de conocimiento y el pensamiento crítico. Y si por estas razones el camino de mi reflexión sobre un "lenguaje del exilio" lleva ineludiblemente a ellas, deseo partir de uno de sus poemas porque en este terreno (el de la poesía) se produce naturalmente un pacto de lectura que da por sentado el protagonismo de las palabras y entonces ese sometimiento a su ley que deseara Mallarmé, pacto que, me parece, debe reproducirse cuando se tratan los relatos de Roa.

El título de dicho poema, "Apátrida", incluye de lleno en el problema

\author{
sido útil el artículo de $\mathrm{S}$. Chejfec. \\ 4 Incluyo copia del poema para facilitar la lectura de este artículo: \\ Apátrida \\ por mucho que oprima tus manos \\ tu harapiento fulgor \\ te vas de mí te fuiste \\ no vendrás en mi seguimiento \\ partido de ti huyendo hacia ti \\ deidad quimera ser cuyo nombre se escribe \\ con p de páramo en clave de agua \\ con ay de piélago \\ ahora mismo te siento \\ aullar a mis espaldas \\ seguidora implacable en tu irte \\ sacudiendo en la sombra
}

3 Para la entropía respecto de la información y comunicación, véase Eco. Para la entropía respecto de la narración ha 
que considero y en la negación (A como privación o separación) que deviene en lo irresuelto de principio a fin: el vínculo irrealizable entre un yo y un tú, un vínculo sólo posible en el espacio de la página, en la contigüidad obsesiva de cada verso, de cada estrofa. Si la palabra que es título irradia a la condición de un sujeto (el apátrida es el sin patria), el poema es, como la poesía en general, discurso destinado a un "tú" en clave femenina, la Patria. Entonces podría jugarse el juego de Roa, regresar al título, descomponerlo y considerar a su vez la A de Apátrida como vehículo de destinación (para) donde la destinataria es una Patria cuyo nombre propio (Paraguay) sólo se sugiere desde partículas de inicio y fin ("con p de páramo en clave de agua / con ay de piélago").

Como se sabe, en Occidente el nombre da identidad a la cosa: desde los lógicos a los taxonomistas lo que no tiene nombre es como si no tuviera ser. Por otra parte, la cultura guaraní es de la "palabra dicha", por eso la

tu enjambre de sol

mis llagas como pulgas

en este instante aquí

tu ausencia soy

tu fuiste mi posteridad

tu antepasado seré

de noche cuando pasean los gatos

entre los vidrios rotos de las estrellas

cuando arde en el vacío

la lágrima seminal del solitario

me aferro a tus cabellos

largos como la angustia

calva deidad distante esfinge

gemela de la luna llena

el humo allá a lo lejos

mansamente llovizna su heredero rocío

hacia los cielos de arena de tus ojos

no existo para ti

tus miradas no recuerdan

lo que no ven 
etnografía guaraní funda su trabajo en la lengua como el mejor instrumento ${ }^{5}$, porque todo en la cultura guaraní es palabra y por ésta se otorga estatuto a todo. Entonces, no escribir / no decir el nombre de, esto es, la Patria, fija doblemente una falta. Pero la partícula "ay" del verso citado, si cierra tanto ese nombre ausente (Paraguay) como la primera estrofa ("con ay de piélago"), no constituye la palabra piélago según dicho verso afirma: es una interjección de dolor asociado a esa falta, que lo expresa en su intensidad primera, lo presentiza, eternizándolo como sonido o profundo lamento (y el sonido en la cultura guaraní tiene el mismo valor que el signo en Occidente). ${ }^{6}$

La ausencia del nombre se tensa sin embargo, con la presencia de ese tú que ocupa demasiado espacio, tanto por alusión a su inconmensurabilidad (reparemos en los tres sustantivos usados- páramo, agua, piélago ${ }^{7}$ ), como por su registro a través de una recurrente segunda persona en diversas formas (tus, tu, te, ti) que en la estrofa tercera se subraya por el uso anafórico y le otorga centralidad ("tu ausencia soy/ tú fuiste mi posteridad / tu antepasado seré"). Pero esta segunda persona, que cuando es "tu” siempre es sin tilde aun requiriéndolo 8 , implica necesariamente la primera, un "yo" indicado en general a través de verbos (oprima, siento, soy, seré), aunque también en construcciones que lo proponen el opuesto complementario de ese tú, forma de relación muy destacada en el par de versos último de

5 Señala B. Meliá (1980, 80-81):“Fluye del árbol la palabra. Todo es palabra entre los Guaraní...”

6 La asociación pay, inevitable por la diferenciación tipográfica, la anáfora y la cercanía espacial, recuerda a pa'í (sacerdote). En algunos anales religiosos de los Guaraní, el Pa'i es el Señor, por ejemplo Pa'i Rete Kuaray, el Señor de cuerpo resplandeciente como el sol, el hombre-dios de la raza, una forma del Padre. Como se sabe, la palabra "patria" (femenina) etimológicamente remite a lo paterno (masculino): Patria es por ello una palabra totalizante, que conjuga lo femenino-masculino.

7 La elección de estas palabras remite a lo geográfico y a lo histórico: Paraguay es un país muy irrigado y J. G. Rodríguez de Francia, durante su gobierno, lo aisló constituyéndolo en una isla rodeada de tierra.

8 En las versiones consultadas, tú como pronombre personal carece de tilde. En guaraní el acento muy pocas veces tiene un papel distintivo (Cfr. Bareiro Saguier, 1983, 313 ) 
esa misma estrofa, que así recarga la centralidad refierida, una centralidad asimismo potenciada visualmente por la anáfora ("tu fuiste mi posteridad / tu antepasado seré”). De ahí la alusión inicial a un vínculo sólo visible (sólo posible) en las palabras.

Esa presencia obsesiva se asedia, se rodea, se atraviesa desde términos que se suceden y abren a lo antagónico (páramo- piélago), a lo diverso encadenado (deidad quimera ser), gesto que si respecto del yo-tú afirma la complementariedad de los opuestos, en relación con el "tú" orienta a la irresolución durante el escribir-decir, otra imposibilidad aquí presente vuelta sufrimiento, aunque del significar: la Patria es lo que no se tiene, lo que no se nombra y lo inasible con el lenguaje, es el objeto de deseo que convoca, no puede capturarse y, sin embargo, impulsa una escritura que incluso destinada al fracaso -y por ello mismo- no cesa. Si "seguidora implacable en tu irte" es un verso que resume la presencia-ausencia y fija el protagonismo del tú en la privación del vínculo, también recae en la permanencia de esas imposibilidades (el deseo es eterno) que los "ahora mismo..." /"en este instante aquí" refuerzan al actualizarse en cada acto de lectura, cada vez. Se trata de un continum -exilio-escritura- asociado a la negación (no tener patria- no poder significar), un siempre presente que anticipa ese "ay" del lamento eternizado en el fin de la primera estrofa.

La negación, incluida indirectamente en el título, propuesta como constante de un vínculo imposible, cierra el poema a través de la palabra que mejor la expresa: "no". Esta palabra, nunca antes escrita-dicha, se menciona dos veces en el final, abre y cancela la última estrofa ("no existo para ti /.../lo que no ven") de un poema que parece alzarse en una grieta -del no tener- no poder, pero que es por y pese a ella (y resulta difícil no recordar a Cesar Vallejo). Interesa cierta concatenación de órdenes hacia una reflexión sobre la

9 Roa encadenaba palabras para indicar, entre otras cosas, opuestos que en su complementariedad hacen estallar significados establecidos. En este sentido, los juegos de Yo el Supremo son reveladores. 
escritura de Roa. Me refiero a la transición natural entre lo humano y lo cósmico, lo abstracto y lo concreto, lo espiritual y lo material, una manera de percibir y aprehender que tiñe de calidad sensorial -especialmente visual10- sus textos. En el caso de "Apátrida", en la primera estrofa, en el primer intento de nominar al "tú" se instaura una circulación por dichos órdenes desde tres palabras enlazadas (deidad quimera ser) que constituyen funcionalmente un término, el cual también oficia de sujeto (aquello de que se habla) de una construcción subordinada. Esta ligazón, patentizada en el ejemplo, concentra la marca del todo, un poema donde el lector es desplazado por un lenguaje que incluye "sin esfuerzo" en lo más abstracto y lo más concreto engarzados, y que restituye sutilmente una modalidad o forma de percepción que así opera.11 Roa Bastos ha señalado la necesidad de transmitir la "emoción vital" del guaraní en su escritura en castellano y los críticos que controlan ambas lenguas han revisado esta posibilidad ${ }^{12}$ que deseo recuperar en relación con lo señalado y con otro tramo del poema a efectos de lo que vendrá.

Como anticipé, la tercera estrofa es central porque allí se llega a un punto climático, cuando se condensa, al conceptualizarse, la índole del vínculo yo- tú ("en este instante aquí/ tu ausencia soy/tú fuiste mi posteridad/tu antepasado seré"). Es decir, se despliegan yo y tú en relación (dos palabras vacías que pueden encarnar en cualquiera), atravesados por el tiempo que las formas verbales de "ser" precisamente imprimen (pasado/presente/ futuro), y por el espacio desde el adverbio (también vacío, de significación ocasional); esto es, tiempo y espacio configurados para instaurar una con- 
tinuidad que se propone incesante a partir de la actualización que cada acto de lectura posibilita. Desde ese punto climático se salta a una estrofa que en inicio proyecta un plano anecdótico, de lo cotidiano ("de noche cuando pasan los gatos / entre los vidrios rotos de las estrellas...”): un lenguaje (un saber) muy pictórico potencia el fluir pese al corte y la quiebra semántica respecto del previo; de la máxima intelectualización se circula a una imagen, a un dato que el ojo ha percibido, y dicho fluir otorga el mismo estatuto a ambos tramos. Por ello me parece que la respiración de esta escritura es de tensión: el enaltecimiento de la calidad visual incentivaría el cómodo fluir, nuestro sencillo deslizamiento (aun entre lo disímil) y entonces, el efecto de naturalidad, pero a su vez la acentuación de ciertas zonas a partir de las metáforas induciría a la compenetración, al refuerzo de la inmersión del lector en ese fluir, profundizando lo que Roa define como "emoción vital" y que sólo la elección de las palabras como signos-sonidos logra producir.

\section{DE IMÁGENES Y METÁFORAS}

"Escribir al mismo tiempo que visualizar las formas de otro lenguaje compuesto exclusivamente con imágenes, por decirlo así, de metáforas ópticas". ${ }^{13}$ Es una anotación en el "Cuaderno Privado" del Supremo, la novela que funciona como un "sol" en el sistema narrativo de Roa pues a ella remite el resto de modo diverso y desde ella es posible pensar todo, ya como continuidad ya como ruptura. ${ }^{14} \mathrm{La}$ frase se inserta en un largo fragmento a modo de nota al pie, cuando se describe detenidamente la "pluma-memoria" del Dictador (el Supremo, pero además, el que dicta). A su vez es una pretensión de Roa expresada como motor de una búsqueda 
estética donde destaca la trastienda de su productividad en marcha -marca que signa el gran texto-, un fondo siempre abierto y dispuesto sobre la superficie, entregado a un lector que se enaltece como componente ineludible de un proceso -lectura-escritura- inexistente si no lo involucra. ${ }^{15}$ Considerada esta observación en diálogo con lo señalado en el cierre del apartado anterior, en la narrativa mayor de Roa tanto las imágenes como las metáforas constituirían zonas de aparición y anclaje de una memoria cultural, nudos enlazados que irradian a una significación y subrayan, en relieve, lo argumental al entramarse en su devenir. Serían operatorias que potencian el gesto de habitar la escritura que todo acto de lectura implica, así como un efecto de retención o permanencia en el recuerdo (y lo que se puede recordar es lo único que se sabe según las tradiciones de base oral), entonces, de resguardo de ciertas regularidades perdidas.

Hijo de hombre [1959], la primera novela de Roa, muestra una tendencia reafirmada en relatos mayores como El fiscal [1993]. Si es posible definirla como una novela de la guerra del Chaco paraguayo, resulta mucho más pues recupera un proceso histórico signado por la marginación política y social, la violencia y la muerte, el enfrentamiento entre civiles y militares, el trabajo-castigo o la enfermedad- la lepra, la locura..., que se remonta a la llegada de los europeos y se desplaza a la época de las Misiones, la dictadura de G. Rodríguez de Francia, la guerra de la Triple Alianza y el levantamiento del '12. Interesa su referencia en este ensayo porque su calidad sensorial -esencialmente visual-opera respecto de mi hipótesis.

En atención a la ficción de lo histórico-social que lleva adelante Roa, se ve de principio a fin de la novela que las imágenes asociadas con la tierra, el color marrón o lo descarnado particularizan a los personajes compro- 
metidos con insurrecciones -únicas alternativas para modificar un orden execrable-, a quienes el grupo sostiene y respeta (Macario Francia o Cristóbal Jara son buenos ejemplos ${ }^{16}$ ). La analogía con esa tierra se refuerza por la descripción de manos y pies descalzos, una marca reiterada en todo el desarrollo, signo de esa conexión con el destino de la comunidad por la cual se lucha sin otro interés que el bien común. El encadenamiento de imágenes se activa por la inclusión de otras del mismo campo semántico aunque opuestas, que particularizan al personaje desarraigado voluntariamente, quien -nada en vano- arrastra los "vicios" de la lectura y la escritura, Miguel Vera. ${ }^{17}$

La repetición y encadenamiento de imágenes produce en Hijo de hombre una concentración semántica entramada en el relato al punto que puede revisarse particularmente; su sintaxis revela una coherencia completa con el argumento y las constantes noveladas (la oposición entre lo individual y lo colectivo, la figura del revolucionario paraguayo arraigado a la tierra por la que lucha y a los otros, entre mucho). Por esto la escritura está atravesada, en su extensión, por una densa línea que, en ciertos momentos, desde lo visual restituye y recupera (para resguardar) esquemas perceptivos y apreciativos que también significan, privilegiando los sentidos. Así, las formas lingüísticas del castellano escrito parecen resemantizarse hacia ese efecto de "emoción vital" propia del guaraní y dicen de otra manera lo que se está contando a partir del argumento.

"Escribir al mismo tiempo que visualizar las formas de otro lenguaje compuesto exclusivamente con imágenes..." Es una frase que si permite pensar los relatos mayores de Roa, también enlaza textos fronterizos bre-

\footnotetext{
16 Incluyo dos citas. Sobre Macario: "Brotaba en cualquier parte... A veces se recostaba contra un mojinete hasta no ser sino una mancha más sobre la agrietada pared de adobe" (Hijo de hombre, 13). Sobre Cristóbal: "Su semblante terroso era el paisaje en pequeño, hasta en los rastrojos de barba" (Ibid., 101 y 98).

17 "Estaba descalzo; sus pies no eran los de un campesino. En el puño crispado sobre el pecho, el haz de sol dejaba ver unas delgadas falanges y el dorso veteado de venas azules" (Ibid., 112)
} 
ves como "El ojo de la luna", cuya pertinencia respecto de mi desarrollo la dan lo que dice y la manera de decirlo. ${ }^{18}$ Es un texto dedicado a su hijo Augusto (pintor) donde Roa despliega su pasión de narrar, ese saber que mencioné antes. De modo equilibrado engarza las lecturas -pictórica y narrativa- que produjeron dos testigos "irrecusables" -testigos y narradores los llama- de la Guerra de la Triple Alianza: "un oscuro cronista pictórico", el argentino Cándido López, y "un segundo testigo y narrador en prosa”, el famoso inglés Sir Richard Burton. ${ }^{19}$ Aquí se expresa la valoración de los dos códigos (escrito-pictórico) respecto de contar un mismo acontecimiento, homologados por una escritura que de modo natural intertextualiza y mediatiza los productos, pese sus diferencias. A veces por separado, otras entremezclados, citados o comentados, las "Cartas" de Burton y los cuadros de López van constituyendo, al ser entrelazados, un nuevo texto que Roa teje y satura con su propia modalidad. "Por momentos no se sabe si Richard Francis Burton está relatando en sus cartas lo que vio realmente, o si está traduciendo las visiones de delirio de esa guerra fantasmagórica que dejó en sus cuadros el pintor enajenado" (Roa Bastos, 1991, 14). Y al referirse a Burton, Roa describe su propio gesto respecto de ambos cronistas en este texto-relato (leído-visto antes de ser escrito) que en ocasiones se dispara ficcionalmente y asigna a ambos registros (escritura-pintura) el mismo estatuto. El saber narrar de Roa se asocia aquí a la muestra de un saber pictórico transfundido a la escritura -que en El fiscal llega al paroxismo- donde la visión es protagonista -el título del texto breve dirige hacia dicha marca

18 En Vigilia del Almirante $(1992,159)$ Roa explica un fundamento de su poética, que el cierre del Supremo también delata: decir por la manera de decir, relacionado con la concepción de la palabra escrita como leída- robada: "Las palabras y las frases que he robado de los libros, robadas a su vez de otros libros, están ahí, sobre los folios, vacías de su sentido original. Para que digan algo de lo mío, yo necesito vivificarlas con el aliento de mi propio espíritu; decirlas con mi manera de decir que dice por la manera”. Exploro estas cuestiones en Marinone (1997).

19 Las expresiones entrecomilladas son de Roa (1991,13). Se trata de las Cartas desde los campos de batalla del Paraguay y de la colección de escenas pintadas por Cándido López que se encuentran en el Museo Nacional de Asunción. 
y la cita anterior recupera la percepción visual en juego (aun la propia).

La Guerra Grande (la de la Triple Alianza), las figuras de Madama Lynch y un Solano López crucificado enlazan "El ojo de la luna" con El fiscal y nos regresan a Hijo de hombre. Si la intertextualidad constituye toda escritura y es un principio de producción expresado por Roa para su poética, la auto-intertextualidad es otro gesto reconocido -por él mismo y es claro, por la crítica- que impulsa la vocación de recuperar expansivamente ciertos núcleos de la propia escritura ${ }^{20}$ y canaliza su obstinado tejer-destejiendo para cuestionar cualquier certeza. Así Roa asedia por ejemplo, el problema de la significación y pone en letra su afán sistemático de desmontar toda pretensión -inútil- de fijarla o cancelarla, hasta (especialmente) la propia, instalando la brecha inquietante entre las palabras y lo que se intenta referir. Gaspar Mora de Hijo de hombre, benefactor y amado guía espiritual de la comunidad, el músico leproso consagrado a los otros, cuyo recuerdo se sostiene por el relato de su tío, el viejo Macario Francia, talla en el monte un Cristo de madera mientras la lepra carcome su fisonomía y será el último legado para su pueblo. La talla, plantada en el cerro de Itapé, emblema del sufrimiento del hombre, del sacrificio, la entrega y el dolor irradia a la frase que da título al primer capítulo y a la novela, tomada del Libro de Ezequiel e incluida en uno de los epígrafes ("Hijo del hombre, tú habitas en medio de casa rebelde... XII, 2). El otro epígrafe corresponde al Himno de los muertos de los guaranies. ${ }^{21}$ Gaspar Mora es introducido, de modo diverso, en

20 Madama Sui [1995] por ejemplo, la novela centrada en el amor de infancia, eterno y puro, de una extraña amante del tirano paraguayo, una joven mujer que vivió en las décadas del 60 y 70, retoma de tal modo zonas de Contravida [1995] que sus finales se ensamblan, pudiendo leerse como consecutivos o casi simultáneos, no sólo por los hechos coincidentes que las cierran, sino por la repetición de palabras y hasta de construcciones que establecen dicha vinculación de manera provocadora. Precisamente Contravida es, entre mucho, una autobiografía literaria que reescribe la primeras zonas de su narrativa, cuentos muy significativos de Roa ("Moriencia", "Nonato", etc.). Desarrollo esta cuestión en Marinone (1996).

21 Ese libro de la Biblia se centra en el profeta que por mandato de Yahveh debe realizar la denuncia de los sufrimientos y de las derrotas del pueblo de Israel (Ezequiel es a quien Yhaveh nombra como "Hijo de hombre"). 
lo que respecta a lo sensorial: a diferencia de los héroes vinculados con las insurrecciones, de fuerte impronta visual, para él lo auditivo y lo olfativo son relevantes; es decir, los sentidos de máxima profundización signan a un personaje que instaura lo religioso desde su música y desde ciertos valores, otras formas de religación: "Gaspar olía a madera... " (Hijo de hombre, 83); "Al oscurecer se ponía a tocar la guitarra que estaba fabricando... La gente se tumbaba en el pasto a escucharlo. O salía de los ranchos." (Ibid., 20).

El Cristo de Gaspar, Solano crucificado, la cruz y la Crucifixión son imágenes metafóricas de clara función sígnica, que además de incidir en la economía de cada relato (en el significar), establecen diálogos entre los textos, hacen olvidar los límites del objeto "libro" y vuelven presente la concepción de un sistema narrativo donde dichos textos, aun acabados, aun pareciendo diferentes, se refieren, se encadenan armónicamente, resuenan y se nutren trayendo la totalidad cada vez.

\section{LO OUE SE REPITE, EL LUGAR DE LA MEMORIA}

El fiscal es la novela que sigue a Vigilia del Almirante [1992] y ambas rompen la clausura en que cayera el corpus de Roa por dieciocho años. Es otro relato que explora el "monoteísmo del poder" y sus consecuencias (como Hijo de hombre y Yo el Supremo, según se anticipa en su comienzo a modo de confesión de parte ${ }^{22}$ ) donde se critica la dictadura de Stroessner de manera tan fehaciente y reiterada que parece un decir obsesivo, una denuncia redundante de la violencia como modo de forzar la red de información institucional e institucionalizada. ${ }^{23}$ En mi consideración sobre la escritura de Roa vinculada con el exilio, esta novela "maldita" (así la definió) se alza 
como una zona de llegada que si absorbe "El ojo de la luna" en tanto relato y arte poética o se encadena a las otras novelas desde cruces y repeticiones, es además atractiva porque oscila entre la "figuración" y la "desfiguración" que el gesto autobiográfico imprime24, pareciendo conjurar mucho, entre lo que destaco el estado de exilio como una condición flotante que marca la vida entera de este narrador.

Sin embargo El fiscal también es mucho más. Es todo lo que las grandes máquinas de narrar de Roa, siempre impulsadas por un afán totalizante, comprimen entre los márgenes de un objeto impreso demoliendo las pretensiones de clausura de cualquier interpretación, lo que hace reconocer la relatividad de nuestro propio ejercicio (y es el sufrimiento de la significación transvasado a todos los juegos de lenguaje, aun éste). Su impulso constructivo por ejemplo, parodia la trama policial -narrativa y cinematográfica- al armarse, como expresó Roa, sobre la trinidad siniestra que acosa nuestro tiempo- poder, sexo y violencia-, pero desde aquí permite, además, una revisión del paradigma moderno de conocimiento. ${ }^{25}$ Félix Moral, el héroe quebrado, un intelectual paraguayo exiliado en Francia, proscrito político, enfermo de melancolía, guionista de cine y profesor de literatura, intenta una acción liberadora - matar al tirano- que daría sentido a su existencia, pero lleva adelante investigaciones, trata de develar ocultos y complejos mecanismos, soportando el peso del fracaso -muere y paradójicamente es atrapado por la telaraña de una conspiración. Aunque la novela es, asimismo, un discurrir sobre arte pictórico, una interpretación de la producción y la lectura bajo el signo del poder cultural, un cuestionamiento de la industria cultural por la muestra de la sintaxis arte - mecanismos económicos que lo hacen posible; una exaltación de lo femenino -sexual/genérico; una 
teorización sobre la propia productividad, una reflexión sobre los grandes temas -verdad, justicia, valor, miedo, además de lo anticipado, otra versión de la guerra de la Triple Alianza donde destella una crítica a la perversión de las relaciones internacionales, entre otros. Y a la par que conecta con diversas formas de exilio, adscribe a la instauración de redes como una salida posible o al menos una esperanza para nuestras comunidades.

Sin embargo, deseo subrayar el efecto de lectura de esta novela pues recupera algún juicio ya señalado. Pese a su impronta expansiva, inabarcable, los lectores circulamos por ella con comodidad, nos desplazamos por zonas geográficas o en la pura interioridad, accedemos a cultura, historia y política en diálogo así como a tiempos diversos en resonancia que el gesto paródico y la exacerbación intertextual-interdiscursiva proponen, desde un flujo que el (trabajo sobre un) lenguaje descomprimido, casi neutro propicia, un lenguaje factible de ser traducido, por ende facilitador de una posible circulación de la novela como parte de un proyecto de política cultural nunca abandonado. ${ }^{26}$ Todos son gestos que instauran y cultivan, a su vez, una mirada fronteriza e interferida, propia de la globalización, abierta a múltiples escenarios y realidades.

En relación con mi hipótesis, el montaje del texto (y cuando se trata de Roa, la noción de tejido barthesiana es muy adecuada) responde a un diseño por el que la puesta en letra se ve entretejida por imágenes de gran fuerza visual que actualizan una de las formas como el poder se pone en escena, esto es, su inscripción desde la violencia en los cuerpos como entidades ya biológicas ya sociales, a través de dispositivos represivos y aun del "derecho" a disponer de la vida y la muerte. Valerse de dicha estrategia permite a Roa manipular lo no controlado en lo relativamente controlado 
(el espacio de la página), desmontar mecanismos perversos que un orden de esa índole ampara y mostrar sus efectos recurriendo a la utilización de sus propios medios. Me refiero a la espectacularidad por ejemplo, esa estrategia por la cual el poder afirma su energía. ${ }^{27}$ Pero al mismo tiempo le permite articular un modo diferente de contar, donde fragmentos pasadoscuya elección no es caprichosa- se entrelazan con instancias actuales sin perderse, un modo que enfatiza la valoración del presente de la escritura (como en "Apátrida"), el único lugar donde, como dije, todo es posible, especialmente la superposición de dichos fragmentos que entonces no se pierden porque allí se recuperan-fijan-recuerdan.

La parodia del género policial- especialmente cinematográfico ${ }^{28}$ - ayuda a este montaje, por esa relación analógica que instala entre un suceder y un focalizar imágenes como detalles esenciales, recuperadores del tema. Roa juega con el cuerpo transformado en sus rasgos desde la apertura de la novela

Sólo he tenido que tomar un nombre falso, despojar al yo de su imposible sinceridad, mudar de aspecto, inventarme nuevas señas particulares: espesa barba tornasolada por canas rubiáceas, una honda hendidura en el arco cigomático, y, sobre todo, dominar perfectamente la lengua (francesa) con el acento y la entonación de provincias. Aprendí a simular a la perfección la renguera del inválido y la parquedad silenciosa del que no quiere papar ni tragarse moscas, habida cuenta de que más pronto cae el hablador que el cojo, y de que la renguera siempre inspira compasión y antipatía, dos elementos siempre útiles en la relación con el prójimo prepotente (El fiscal, 14)

27 Sigo a Balandier.

28 Roa fue una gran guionista de cine durante su exilio en Argentina: Detallo algunos títulos: Alias Gardelito, La Boda, Castigo al traidor, La Cosecha, Don Segundo Sombra, Hijo de hombre (titulada también La sed y Choferes del Chaco), La Madre María, El Señor Presidente, Shunko, Soluna. 
comprasfflch@usp.br Sin embargo Félix Moral, además de cambiar sus actitudes o su nombre (la primera gran falta, según consignamos en "Apátrida"), ha completado su transformación sometiéndose a una cirugía facial y dactilar como estrategia de borradura de su identidad en el exilio. Resulta difícil no recordar a Gaspar Mora siendo tallado por la lepra, auto-exiliado en el monte, o no realizar una lectura densa de dicha borradura de las facciones en tanto huellas y marcas particularizadoras, respecto de la pérdida de regularidades de una cultura que se porta y deja de ser pulsada en lo cotidiano -esa sustancia que los narradores tanto valoran- por el alejamiento de la propia tierra.

Aunque este proceso de transformación de Félix se remonta a un tiempo anterior: fue iniciado en el Paraguay, en las sesiones de tortura o inscripción de la violencia en su cuerpo, cuando se lo apresa tras un atentado fallido contra el mismo tirano. El enlace de ambas instancias lo produce el campo semántico: "Me conoció antes de que la cirugía plástica me dibujara esta nariz judía y la cicatriz de un hachazo en el pómulo izquierdo (...) (ibid.,18). También: "En los "quirófanos" de la Técnica nada había cambiado. El instrumental consagrado a las sevicias, salvo algunos adelantos, seguía siendo el mismo. (ibid., 253)". ${ }^{29} \mathrm{O}$ bien:

Como entre las resonancias de un acueducto que reverberan en todo el cuerpo machacado, y bajo la tapa del cráneo a punto de estallar, se escuchan lejanos los gritos de los torturadores encapuchados en una rojiza niebla. (ibid., 254)

La palabra proceso no es arbitraria dado que hacia el final de la novela se cierra un círculo: la transformación del cuerpo de Moral o superficie material 
del acontecer hace visible su / la historia, cuando producido el fracaso del nuevo atentado contra el tirano "se venía arrastrando a gatas. Era una piltrafa humana semidesnuda y mutilada, con rastros de salvajes castigos y torturas" (ibid., 391).

Estas imágenes de Moral esparcidas en el relato se fortalecen al enlazarse a otras articuladas del mismo modo (esparcidas intermitentemente), que resemantizan la crucifixión; son, como en "El ojo de la luna", transposiciones verbales de escenas pictóricas o cinematográficas. Por una parte, todas contribuyen a estructurar o reorientar un sentido muy diseminado, y por otra, anticipan el final de la historia (el fracaso del héroe que se sacrifica) expandiendo la anécdota hacia esas zonas anteriores de un proyecto narrativo completo y a través suyo, hacia otras fundantes de un proceso histórico de formación, un archivo saturado de dos códigos culturales (occidental-guaranî), de ahí que operen como artefactos donde la larga tradición y el presente se asedian. Es decir, la imagen de la crucifixión asociada a Félix Moral es otra marca que lo acerca a Gaspar Mora, el guía espiritual, y a los leprosos, los guardianes de Hijo de hombre $e^{30}$, quienes además de un compromiso con la lucha y las insurrecciones por la liberación de su pueblo o con un espíritu solidario fundando cada acto heroico y de renunciamiento, metaforizan en las marcas de sus cuerpos, en su mutilación y sus pústulas, la violencia, las injusticias y la represión que todos han padecido y padecen, esto es, el "dolor paraguayo". 31 Aunque lo interesante es que el signo de la cruz, los palos cruzados $^{32}$ son un nudo de la cosmogonía guaraní asimilado

30 Son funciones que implican dos modos de trascendencia en Hijo de hombre.

31 La frase es de Rafael Barrett. Roa se refería a él como "otro español ejemplar que también adoptó el dolor paraguayo". (Véase Anthropos- 25, 1991,82). Este reconocimiento valora a quienes aun no siendo portadores nativos de una cultura pueden hacerse cargo de ella a través de su pertenencia a una comunidad de destino.

32 Señala Roa: "El Paraíso cristiano como lugar de bienaventuranza eterna coincidía con el mito intemporal de la Tierra sin males. Del mismo modo que muchos otros mitos y símbolos religiosos, tales el primer Padre... los palos cruzados (yvyrá yuasâ) como sostén de la morada terrenal, asimilado e identificado por los misioneros con la cruz cristiana." (Cfr. Anthropos 25, 1991,44) 
por los misioneros que entre todo, reedita la llegada de los europeos al continente, una integración forzada, el principio de políticas discriminatorias, esa suma latente tras los acontecimientos históricos, las experiencias colectivas y los ciclos de violencia novelados por Roa de modo diverso.

La crucifixión como imagen cultural e ideológica asociada a Félix es explotada en El fiscal desde el personaje del Mariscal López, protagonista de la Guerra de la Triple Alianza (1865-1870), el Cristo paraguayo según dejara establecido el capellán de su ejército sacrificado en Cerro Corá. Esta Guerra, la primera gran contienda internacional de nuestro continente, que dejó al Paraguay sólo con mujeres, ancianos y niños, es una de las causas que interrumpen drásticamente la real consolidación de ese país como nación, pues devasta su cuerpo social al acabar con los hombres, desmembra su territorio, destruye su paisaje y economía. La imagen de Solano crucificado, escena de un film cuyo guión escribe Félix e imagen en la que resuena el Cristo del retablo de Mathaeus Grünewald traído por descripción o referido, es una matriz de significación totalizante que recupera ese aniquilamiento:

Solano estaba ahí, clavado en la cruz de ramas mal descortezadas, como el Cristo del retablo de Grünewald. Más trágico aún que en aquella espantosa representación. Solano estaba ahí desnudo, emasculado, monstruosamente deforme, la lanza atravesada en el costado. Estaba ahí, negro de moscas, y avispas que libaban en las bocas tumefactas de las heridas la vejación del pus. La última iniquidad de los vencedores se cifraba en esa insignificante y miserable enormidad. (ibid., 34)

Pero además (y "El ojo de la luna" reverbera) esta matriz le permite engarzar a ese cronista- testigo ocular de la Guerra, Cándido López, no solo porque registra la índole devastadora del acontecimiento en su obra monumental o pintura de los hechos- entre ellos la crucifixión de López, sino 
porque él mismo resulta mutilado en la contienda. ${ }^{33}$ La expansión ficticia cobra extenso vuelo desde este dato biográfico y el Cándido López de Roa, ese "narrador irrecusable", es el "cronista pictórico" que queda reducido a la "nada física", se asume como "metáfora corporal" de la tragedia de un pueblo, se transforma en paraguayo por ese gesto de hacerse cargo del "martirologio colectivo" y se encadena a la serie de poderosa fuerza visual que intento reconstruir:

Cándido López pintó en cuadros memorables la tragedia de la guerra, pero su propio cuerpo era el comentario más terrible de ella. (ibid., 322)

Un trozo de metralla le arranca el brazo derecho. Pronto aprende a pintar con el izquierdo... (ibid., 322)

Un casco de obús le vuela el brazo izquierdo, que ya empezaba a ser diestro (...) Aprende a pintar con el pincel encastrado en los dedos del pie. Sucesivamente pierde ambas piernas a la altura de las rodillas. Aprende a pintar con el pincel apretado entre los dientes.

(...) Su cabeza no se levanta ya más de un palmo sobre el suelo. Lo que es una ventaja para él, pues ahora puede pintar escondido en la maleza, al abrigo de ese cazador que lo persigue desde la muerte. El narrador decrece en la misma medida en que los sobrevivientes van siendo cazados y diezmados. Pero de esa mutilación incesante crece una obra inmensa, bajo el signo de la irremediable locura humana. La imagen final es la de un pueblo reducido al hombre último parecido a todos los hombres muriendo. (ibid., 323-324)

Transcribo largamente a efectos de recuperar algunas ideas dispersas. El proceso de devastación del cuerpo individual (de Cándido), enlazado 
a la Crucifixión y asimilado a la destrucción del cuerpo social, opera aquí como foco concentrador abriendo a diferentes planos. La violencia se espectaculariza, esto es, se estiliza en momentos (escenas) que se suceden y es una operatoria que propone un devenir ininterrumpido conducente a la nada en los hechos, pero fijado para siempre, de modo magistral en el plano simbólico (los cuadros, la escritura), cuyo estatuto cobra fuerza porque es la mejor prolongación de lo real, el lenguaje literario. El juego ficcional permite a Roa abrir las compuertas de su novela y mostrar-se como narrador-testigo a la par que muestra al otro, alzarse también como cronista-pictórico aunque su material sea la palabra, un hombre-memoria como Cándido López, esos a quienes Le Goff (1991, 137-138) fundado en Balandier, identifica como los "narradores en caso de necesidad", los custodios y depositarios de la memoria colectiva cuya función es mantener la "cohesión del grupo" desde contar lo que se puede recordar que, como anticipé, es en última instancia lo que se sabe (según enseña Macario en Hijo de hombre). El efecto de lectura se potencia a través de la estilización y el encadenamiento a una serie que el lector sostiene en el recuerdo por su fuerza visual y recurrencia en lo mismo: la reiteración del aniquilamiento concentrado y parte a parte, la repetición excesiva produce su natural fijación, un modo de permanencia.

Los ojos, la mirada son potenciados como vehículo conducente del acto de producción y de lectura (los ojos de Cándido López mirando la devastación, los de Roa mirando sus cuadros, los nuestros leyéndolos a través del relato), pero además son jerarquizados como palabras, y junto con "cabezas leoninas y deformes", "laceraciones", "pies esponjosos, coagulados, de plantas descortezadas" se constituyen en signos dentro de la serie de imágenes contribuyendo a la traza de esa otra forma de contar. Así, los "ojos turbios y sin vida" de un Félix Moral torturado recuerdan los "ojos inyectados de sangre, vidriosos por la muerte" de Solano y pueden interpretarse a través de los "ojos entreabiertos y cenicientos que manaban una 
infinita mirada de sufrimiento y de terror" del Cristo de Grünewald.

Desde lo expuesto, el cierre de la extensa cita cobra nueva dimensión ("La imagen final es la de un pueblo reducido al hombre último parecido a todos los hombres muriendo"). Si al leerlo se percibe un afán de desapego situacional (la Guerra Grande, el Paraguay), considerada en diálogo con la serie construida y con la imagen cultural de la Crucifixión -la cruz es, recordemos, también una metáfora del cruce de dos códigos- y aun cuando restituye un modo particular (sensorial) de procesar lo real, permite pensar la novela como relato sobre el poder y la violencia respecto de lo humano en general, tal como sucede con todos textos de Roa (tal como ocurre con los grandes novelistas, que pasan por la comarca para llegar al mundo). Si se arman sobre la base de pretextos afirmados porque emergen a cada momento, a su vez sofocan dichos pretextos por aquello que se impone con potencia inusitada, la escritura como tal, finalmente lo que accede a una condición de "real" por el acto mismo de instauración, sumerge así en sus profundidades, propicia una "emoción vital" y lleva a reflexionar sobre esos complejos temas del hombre de que la ficción se ocupa.

\section{EL LENGUAJE DEL EXILIO}

Perfectus vero cui mundus totus exilium est Didascalicon. Hugo de San Víctor ${ }^{34}$

La obstinación de Roa en dotar a su escritura de una calidad visual conduce a sus metáforas ópticas. En El fiscal el calidoscopio asume este rango y desde su etimología $a^{35}$ nos remite a dicho campo -de lo visual: 
... me inventé también un juego, el viejo juego infantil de la linterna mágica, con un calidoscopio que compré en una tienda de antigüedades. Mediante linternas y diapositivas proyecto pequeños cortos coloreados sobre la cal del muro. Inocente esparcimiento de cineasta fracasado. La oscuridad alternativamente iluminada por lo colores del espectro me relajan con su movilidad en una especie de ensoñación que anula el paso del tiempo (Ibid., 31)

Interesa esa palabra de la cita (calidoscopio) y realizar una descripción que compromete desde el enunciado a la enunciación. Dicho artefacto, si reenvía a uno similar usado por el Signore Vittorio, el maestro de Colón en Vigilia del Almirante ${ }^{36}$, entronca con la pluma - recuerdo o pluma- memoria del Supremo (214) ya mencionada, de forma cilíndrica y en cuyo hueco está el lente-recuerdo, "con un dispositivo interior, probablemente una combinación de espejos" a partir del que se proyecta un "chorro" de imágenes móviles. El calidoscopio parece el motor de configuración del Fiscal, casi su cifra. Recuperemos: por una parte Roa entrama al hilo anecdótico -la historia del héroe- imágenes de gran fuerza visual sobre el cuerpo devastado que operan como leitmotiv; si anticipan su final, son zonas de anclaje y matrices resonantes que ensamblan, a ese hilo anecdótico, la historia individual y la colectiva -nacional, continental, occidental-, la larga tradición y el presente.

El calidoscopio produce una especie de "ensoñación que anula el paso del tiempo", una fascinación por la cual las percepciones habituales se disuelven pues los límites, fronteras e identidades rígidas estallan confundiendo lo "real" con lo "irreal". ${ }^{37}$ Las imágenes y las metáforas, por ser matrices resonantes que condensan la significación, contribuyen a la fractura

\footnotetext{
36 "Nunca olvido las palabras del maestro Vittorio y del experimento que hacía con su viejo calidoscopio para demostrarnos cómo el tiempo retrocedía para darnos la sensación de que nosotros avanzábamos." (Vigilia del Almirante, 138)

37 Ibid., 19.
} 
de la linealidad impuesta por la escritura, que se funda en una concepción secuencial del tiempo y en una lógica causa-efecto; al operar como focos recuperadores, orientan a una ficción de tiempo simultáneo. Por ello, la ficción convencional del tiempo para quienes portamos un sistema grafocéntrico estalla y se nos acerca naturalmente a otra modalidad (es el efecto de Moral y el de Colón en la escuelita de Nervi durante sus "experiencias" con el calidoscopio). Pero, además, son operatorias apropiadas para persuadir al lector-oyente respecto de cierta "emoción vital". Roa logra por enlace, yuxtaposición y síntesis espesar el discurso literario; su trabajo con la materialidad misma del lenguaje actualiza un carácter sensorial, una riqueza semántica y musical propios de la lengua guaraní. ${ }^{38}$

$\mathrm{Al}$ escribir en castellano, el escritor, y especialmente el autor de ficciones (paraguayo), siente que está sufriendo otra nueva especie de alienación ética... la del exilio lingüístico. ¿Hasta qué límites puede llevar este alejamiento de la porción de realidad y de vida colectiva que se expresa en guaraní? (Roa Bastos, 1991,88)

Me parece que escribir en el "lenguaje del exilio" ha significado, en el caso de Roa, transgredir esos límites desde una estrategia de composición que, como señalé y deseo repetir, aun basada en saberes, discursos, textos preexistentes o asida a "reales" verificables y localizados que actualizan la relación de los textos con la Historia y favorecen la reflexión sobre lo político o social, se tensiona volviendo sus novelas perdurables por la escritura como tal. Transgredir a través de la imaginación fue entenderla según la describe Starobinski39, como "mucho más que 
una facultad...", como ese "poder de separación gracias al cual nos representamos cosas alejadas y nos distanciamos de las realidades presentes", implicando, en su caso, la figuración de una pertenencia, una figuración obsesiva y perdurable por instaurarse en el mejor lugar, la escritura. El universo de Roa parece ubicado en la estela de la illusio de Bourdieu y proyectado a lo que éste deseara, hacerse y hacernos entender a través de narraciones de las que todavía tenemos mucho que aprender, que ganar.

\section{REFERENCIAS BIBLIOGRÁFICAS}

Baczko, Bronislaw. Los imaginarios sociales. Memorias y esperanzas colectivas. Buenos Aires: Nueva Visión, 1991.

Balandier, Georges. El poder en escenas. España: Paidós, 1994.

Bareiro Saguier, Ruben. "Colonialismo mental en el bilingüismo paraguayo”. In: Escritura 1, 1976, 76-85.

et al. "Esbozo del sistema lingüístico del guaraní paraguayo". In: Pottier, Bernard (coord.). América Latina en sus lenguas indigenas. Venezuela: Monte Ávila, 1983, 311-330.

- "Estratos de la lengua guaraní en la escritura de A. Roa Bastos". In Revista de Crítica Literaria Latinoamericana 19 (1er.semestre), 1984, 24-35.

Bourdieu, Pierre. Cosas dichas. Barcelona: Gedisa, 1993.

Chejfec, Sergio. "Fluir del desorden". In Dominios 9. (Revista de la Universidad Rafael M. Baralt), 1994, 142-144. 
De Man, Paul. "La autobiografía como desfiguración”. In Anthropos 29, 1991, 113-117.

Eco, Umberto. Obra abierta. Barcelona, Ariel, 1979.

Foucault, Michel. Microfísica del poder. Madrid: Ediciones de La Piqueta, 1980.

Le Goff, Jacques. El orden de la memoria. Barcelona: Paidós, 1991.

Lienhard, Martin. La vozy su huella. Cuba: Casa de las Américas, 1990.

Marinone, Mónica. "El bilingüismo desde la escritura de A. Roa Bastos". In: Revista del Celehis, I -1, 1991, 107-117.

. "Travesía por las novelas de A. Roa Bastos". In: Revista de Estudios Hispánicos. Año XXIII, 1996, 199-219.

"Vigilia del Almirante: una variante en la narración de la historia". In: Scarano, Mónica; Marinone, Mónica; Tineo, Gabriela. La reinvención de la memoria: gestos, textos, imágenes en la cultura latinoamericana. Rosario: Beatriz Viterbo, 1997, 114-138.

. "La pasión de narrar: A. Roa Bastos". In: Revista del Celehis 10, 1998, 95- 107.

. "La escritura de Roa revisitada: desplazamiento de fronteras y significaciones”. In: América Hispánica 17 (Augusto Roa Bastos: testemunho e ficçao), 2001, 76-89. 
. "El conjuro del exilio. A. Roa Bastos". In: Bocchino-Marinone-Tineo. Escrituras y exilios en América Latina. Mar del Plata: Estanislao Balder, 2007.

Meliá, Bartomeu. "Hacer escuchar la palabra”. In: Bareiro Saguier, Rubén (Comp.,). Literatura guarani del Paraguay. Venezuela: Biblioteca Ayacucho, 1980, 80-81.

. "La lengua guaraní del Paraguay". In América Latina en sus lenguas indígenas. Venezuela: Monte Ávila, 1983, 43-60.

. "Una metáfora de la lengua en el Paraguay". In: Cuadernos Hispanoamericanos 493/494 (julio-agosto), 1991, 65-73.

Montibelo, Eduardo. "Los vaticinios culturales casi nunca se cumplen". Entrevista a A. Roa Bastos. In: Página 12. Buenos Aires, 2 /07/1990.

Ong, Walter. Oralidady escritura. México: F.C.E., 1987.

Pacheco, Carlos. La comarca oral .Caracas: Ediciones Casa de Bello, 1992.

Quijano, Aníbal. “Colonialidad y Modernidad - Racionalidad”. In: Bonilla, Heraclio. (Comp.). Los conquistados. 1492 y la población indígena de las Américas. Colombia - Ecuador: FLACSO/Ecuador, Libri - Mundi- Tercer Mundo Editores, 1992, 437- 450.

Rama, Ángel. "El dictador letrado de la revolución latinoamericana". In: . Los dictadores latinoamericanos. México: F.C.E., 1976, 20-41.

Roa Bastos, Augusto. Hijo de hombre. España: Revista de Occidente, 1969. 
. Yo el Supremo. México: Siglo XXI, 1982.

"La narrativa paraguaya en el contexto de la narrativa hispanoamericana actual". In: Sosnowski, Saúl (Comp.) Augusto Roa Bastos y la producción cultural americana. Buenos Aires: Ed. de la Flor, 1986, 117-140. - Antología Narrativa y poética. ANTHROPOS 25, 1991. . "El ojo de la luna". In: Cuadernos Hispanoamericanos 493494 (julio-agosto), 1991a, 13-23. . Vigilia del Almirante. Buenos Aires: Sudamericana, 1992.

Said, Edward. El mundo, el texto y el crítico. Buenos Aires: Debate, 2004 